\title{
Measuring Work Related Quality of Life and Affective Well-being in Turkey
}

\author{
Emin Cihan Duyan'1, \\ Prof. Dr. Serpil Aytaç, \\ Neslihan Akyıldız, \\ Dr. Darren Van Laar ${ }^{2}$
}

\author{
${ }^{1}$ Uludag University, ${ }^{2}$ University of Portsmouth
}

E-mail: eminci@gmail.com

Doi:10.5901/mjss.2013.v4n1p105

\begin{abstract}
The prime purpose of this research wass to test the cross cultural construct validity and the reliability of the Work Related Quality of Life (WRQoL) scale developed by Van Laar and colleagues (2007) and Job Related Affective Well-being Scale by Sevastos (1996). 288 employees participated in the study from a range different occupational backgrounds. The employees had a mean age of 34.25 years and average work experience of 12.17 years. $52.1 \%$ of the participants were men. Three items needed to be removed from WRQoL according to the CFA results and the new structure for Turkish version of the WRQoL consisted of 20 items and 6 factors with acceptable to good fit indices. Job related affective well-being scale showed a consistent factor and item structure with the Turkish sample indicated by good fit indices. All sub-scales and scales showed significant correlations. We might consider that the 20 item WRQoL and 12 item job related affective well-being scae are both valid and reliable in a Turkish context.
\end{abstract}

Keywords: qulity of work life; job related affective well-being;

\section{Introduction}

Quality of working life (QWL) is becoming more important with each passing day for employees. Along with changes in work culture, the concept of traditional work, which was contented with meeting the basic needs of people, simply has changed. Changes in living standards and working systems have led to the changes and diversifications even in basic needs (Rethinam \& Ismail, 2008).

Under these circumstances both quality of work life and well-being have become important issues for organizational behaviour studies. The need for working on developing measures and improving these variables of work arose in order to create more effective and happy employees whom are one of the most important aspects of organizations.

With the present study it has been aimed to measure quality of work life and job related well being of the employees in Turkey by translating and adapting the Work Related Quality of Life Scale (Van Laar et al., 2007) and Job Related Affective Well-Being Scale (Warr, 1990; Sevastos, 1996) into the Turkish language and context.

\section{Quality of Working Life}

Quality has become mandatory for organizations out of necessity. In our age, it is observed that a large number of organizations have been dedicated to providing the best business culture. In addition, the most important asset for the organization is high quality manpower. Quality of human resources depends on the quality of working life (Jayan, 2012).

Increased union movements in the 1930's and 1940's have led to the demand for improvement in working conditions. Quality of work life began to draw attention due to the difficulties in working life at the end of the 1950's. First definitions of this term stressed employees' reaction to the work especially at the point of job satisfaction and mental health. (Walton, 1973; Cummings and Vorley, 2009)

Although there are nuances, several concepts have been used in the same sense as QWL such as quality of work and quality of employment (Gundogan, 2010). QWL gave rise to the concept of job quality, which is frequently used in studies conducted in EU (Davoine et al., 2008:13; Gündoğan, 2010).

QWL was first developed in the United States and UK, then spread to Norway, the Netherlands, India and Japan (Davis \& Trist, 1974). Transition processes, perspectives and practices of QWL vary between countries. For example, 
leading countries in Europe are Norway with its "industrial democracy" program, Sweden on the subject of "the democratization of the institutions within the framework of employer-employee-union", UK on theoretical area (Kaymaz, 2003). The concept of QWL is associated with the improvement of working conditions in France, with humanization of work in Germany and with employee protection in Eastern European Countries, (Huzzard, 2003). North America, Europe and Japan not only consider QWL as a tool of efficiency but have also discussed/examined it in terms of democracy and humanization of the working environment (Wyatt \& Wah, 2001).

QWL is related to employee's mental, physical, psychological and spiritual needs (Schulze, 1998 and QWL is based on a management philosophy which seeks to increase the level of physical and psychological well-being and reputation of employees and to change organizational culture (Ivancevich \& Matteson, 1996).

Definitions of QWL put emphasis on different points. Some researchers have focused on the relationship between work environment and work performance while others have concentrated on well-being (Huzzard, 2003).

Newstorm and Davis (1997) defined QWL as the degree which employees meet their important personal needs through work. According to this, QWL covers all topics related to workplace, not only favourable subjects as job satisfaction, development of employee skills, wages, health, safety and the improvement of the physical conditions but also issues such as stress, burnout which are unfavourable for employees.

Robbins (1989:207) defined QWL as "a process by which an organization responds to employee needs by developing mechanisms to allow them to share fully in making the decisions that design their lives at work".

Sirgy et al. (2001) defined QWL as the individual's job satisfaction of work life. Carayon et al. (2003) considered the human dimension and described QWL as the quality of the relationship between employees and their work environment in addition to the technical and economic aspects. Serey (2006)'s definition of QWL emphasized the need for meaningful and satisfying work.

The European Foundation for the Improvement of Living and Working Conditions (2002) related QWL to job satisfaction, job acceptance, motivation, health, security, safety, productivity, job security, skill development, well-being and balance between work and non-work life. Studies on QWL mostly try to explain the status of employees in their work environment (Limongi-Franca, 2004).

According to (Can, 1991) QWL is a concept covering factors as wages and other benefits, working environment and conditions, work structure, work organization, management and organization of work, technology, employee satisfaction and motivation, industrial relations, participation, employment security, social justice and social security, demographic structure and continuing education.

In its original form, the concept of QWL shows the relationship between the employee and the work environment stressing the human dimension (Erdem, 2010). Originally QWL was been said to focus on the individual, perhaps one who has been pushed aside, despised/ill-treated and alienated, especially because of the development of new technology (Davis \& Trist, 1974).

Runcie (1980), stated that employees with positive opinion regarding the quality of working life would strive for better working conditions, productivity and products. Growing efficiency is the by-product of development in the quality of work life (Reena \& Jayan, 2012).

QWL is a concept consisting of a large number of inter-related elements (Rethinam \& Ismail, 2008). Potential QWL-related elements would form a long list. Elements on which majority of QWL studies appear to agree on (Walton, 1972, 1973; Beach, 1980, Cummings and Worley, 1997; Bowditch and Buono, 1994, Solmus, 2000; Dikmetas, 2006) include the following:

- $\quad$ Appropriate, adequate and fair compensation: Includes elements such as compensation to meet standards, to be sufficient, internal and external fairness, to have similar wages to those of other employees doing the same work, fringe benefits and payments, employee rights, retirement.

- $\quad$ Safe and healthy working environment: Factors such as physical working conditions (cleanliness, lighting, temperature, colours used), ergonomics, workplace security and working hours.

- Developing individual capacity: auto-control, autonomy, providing the opportunity for development and use of capacity and capability, business planning and providing employees information about the process, ability to follow work-related innovations, management support.

- Development and security opportunities: Personal and professional development of individual, career, promotion and advancement opportunities, job security.

- Social integration: Cooperation, organizational trust, sense of belonging and organizational commitment, teamwork, communication, prejudices and conflicts, interpersonal communication and distance are included in this group. 
- Constitutionalism: Including personal immunity, equality right, human rights, privacy, freedom of expression and speech, democratic environment, participation in decision making, knowledge and defence of rights and responsibilities, labour laws

- Total living space: This inlcludes the contains the balance between work, family and private life of individual, working hours, leisure time, time spent for the individual and family, the balance of roles and responsibilities, relocation and so on.

- Social relevance: Social responsibility of the organization, effects of the organization on employees, society and the environment; corporate image, production, human resources, marketing etc. policies, transparency and accountability, on going campaigns, cultural and artistic activities.

In addition to these, other authors have included the structure and organization of the work, technology, industrial relations, participation, job satisfaction and motivation, employment security, social justice and social security, continuing education (Ustundag, 1999), business requirements, administrative behaviour, utilities (Sirgy et al ., 2001), participating organization, social facilities, in-service training, the balance of authority and responsibility, organizational structure (Bayir Toplu, 1999), union participation (Eaton, 1990).

In measurement of the quality of working life, many indicators have been used including performance metrics such as productivity, efficiency and effectiveness; statistical indicators as rates of turnover, absenteeism, accident and tardiness, disputes between employees, number of employees, proposals of employees; comparison of measurements of physical working conditions as lighting, ventilation, heat, noise, dust, vibration, visual and mental concentration and physical effort to standards, surveys, interviews and observations (Akal, 2005).

Many models have been developed to measure QWL these include models by Walton (1975), Hackman \& Oldham (1975), Westley (1979), Wether \& Davis (1983), Fernandes (1996) and Timossi et al., 2008. The criteria and sub-criteria of QWL presented in Walton's model are shown in Table 1.

Table 1. Walton's Criteria of QWL (1975) (Adapted from Timossi et al., 2008)

\begin{tabular}{|rl|l|}
\hline Criteria & & Sub-criterias \\
\hline 1. & Fair and appropriate compensation & $\begin{array}{l}\text { Fair compensation, wage balance, participation in results, } \\
\text { fringe benefits. }\end{array}$ \\
\hline $2 . \quad$ Safe and healty environment & $\begin{array}{l}\text { Workload, weekly journey, process technology, salubrity, } \\
\text { fatigue }\end{array}$ \\
\hline $3 . \quad$ Development of human capacities & $\begin{array}{l}\text { Autonomy, importance of the task, polyvalence, performance } \\
\text { evaluation, given responsibility }\end{array}$ \\
\hline $4 . \quad$ Growth and security & $\begin{array}{l}\text { Professional growth, trainings, resignations, encouragement } \\
\text { for studies }\end{array}$ \\
\hline 6. $\quad$ Social integration & Constitutionalism & $\begin{array}{l}\text { Discrimination, interpersonal Relationship, compromise of } \\
\text { team, valorization of ideas }\end{array}$ \\
\hline 7. & Total life space & $\begin{array}{l}\text { Employee rights, freedom of expression, discussion and } \\
\text { norms, respect to individualities }\end{array}$ \\
\hline 8. $\quad$ Social relevance & $\begin{array}{l}\text { Influence on the family routine, possibility of leisure, time of } \\
\text { work and rest }\end{array}$ \\
\hline & $\begin{array}{l}\text { Proud of the work, institutional image, community integration, } \\
\text { qualities of products/ services, human recourses policy }\end{array}$ \\
\hline
\end{tabular}

Problems have been observed both with QWL studies and in the many applications and interpretation of the Walton model, which is one of the most commonly used models to measure QWL. One issue is the detailed terms and expressions used in the original model while the other point is the absence of direct or indirect questions and comments regarding each criterion (Timossi et al., 2008).

A relatively new measure on QWL is the Work Related Quality of Life (WRQoL) Scale developed by Van Laar and friends(2007). WRQoL measures work and non-work QWL and also stress in the workplace, expanding upon earlier theoretical models. According to Van Laar and friends (2007) the WRQLL scale is one of the most concise, psychometrically valid and reliable QWL measures in the literature. The scale is based on a UK healthcare workers dataset and could be used in healthcare settings worldwide with translation (Van Laar et al., 2007). Further research is necessary to improve the instrument and evaluate its practicability to other areas. Edwards and friends (2009) assessed and reported that the scale is also psychometrically strong for higher education workers. They also suggested testing the scale with a broad range of employee groups and in other cultures. 


\section{Job Related Affective Well-Being}

There are many notions related to well-being in the literature. Pleasure, satisfaction, social well-being, subjective wellbeing, psychological well-being and quality of life are among those notions (Bayram et al., 2004).

Diener and friends (1999:277) suggest subjective well-being to be "a broad category of phenomena that includes people's emotional responses, domain satisfactions, and global judgments of life satisfaction". We might consider the term as people's evaluations of their own lives (Aytac, 2006).

Psychological well-being is defined by Robertson and Cooper (2011:54) as the "affective and purposive psychological state that people experience while they are at work". They suggest that psychological well-being has two major components. First one is hedonic, about feeling good. The second one is eudemonic, which is related to the meaning and purpose that we associate with our work (Robertson and Cooper, 2011).

Obstacles may occur while measuring psychological well-being. Some of the measures may confound well-being with cognitive processes that influence well-being. Also job related psychological well-being might be limited by being used as job satisfaction only (Daniels, 2000). To overcome these obstacles as one of the most important indicators of psychological well-being, affective well-being needs to be assessed (Diener \& Larsen, 1993; Warr, 1994).

Affective well-being includes the frequent experience of positive affects and occasional experience of negative affects (Diener \& Larsen, 1993). Affective well-being can be separated from attitudinal factors of psychological well-being which includes affective and cognitive elements like job satisfaction (Diener \& Larsen, 1993; Warr, 1990). Unlike unidimensional measures, multi-dimensional affective well-being is capable of capturing subtleties, complexities and changes in the experience of work (Briner, 1997).

Adopting affective well-being into work and employees was Warr's $(1987,1990)$ idea in the first place. In practice affective psychological state indicates whether people feel good or not at work (Robertson and Cooper, 2011). Warr (1990) developed a two dimensional model based on emotional states and originated from Russel's (1980) work. The first factor was anxiety-contentment represented by tense, uneasy, worried, calm, contented and relaxed items. Warr (1992, 1994) renamed this factor as anxiety-comfort after Sevastos and friends'(1992) study. Depressed, gloomy, miserable, cheerful, enthusiastic and optimistic items were representing depression-enthusiasm as the second factor (Warr, 1990).

Sevastos (1996) hypothesized the two bipolar scale of Warr (1990) needs to evolved into a four mono polar scale and proved it with a large sample in his doctoral dissertation. The items of Sevastos (1996) were as follows; Gloomy, Calm, Anxious, Enthusiastic, Motivated, Worried, Restful, Tense, Depressed, Optimistic, Relaxed and Miserable.

Katwyk and friends (2000) developed the Job-Related Affective Well-Being Scale

(JAWS) which describes an individual's affective states in the context of the workplace which Bayram and colleagues (2004) adapted le into Turkish. According to the study Job-Related Affective Well-Being consists of four dimensions: High Pleasure High Arousal (HPHA), High Pleasure Low Arousal (HPLA), Low Pleasure High Arousal (LPHA) and Low Pleasure Low Arousal (LPLA). Four dimensions lay on two main axes named low-high pleasure and low-high arousal (Katwyk et al., 2000).

In order to assess job related affective well-being in Turkey, Sevastos' (1996) scale is preferred in this study due to its concise and easy to understand nature with one word items.

\section{Research methodology}

\subsection{Objectives}

The aim of this study is to test the cross cultural construct validity and the reliability of the Work Related Quality of Life (WRQoL) scale developed by Van Laar and colleagues (2007) and Job Related Affective Well-being Scale (Warr, 1990; Sevastos, 1996). We are also interested in investigating the relationships between the Work Related Quality of Life scale and Job Related Affective Well-being in all dimensions.

\subsection{Method}

The Work Related Quality of Life (WRQoL) scale and Job Related Affective Well-being Scale were translated from English into Turkish according to the back-translation procedure (Brislin, 1986), in which a bilingual person translates the scale from its original language to the language under study. Another bilingual individual, who is unfamiliar with the original scale, re-translates this version back to the original language.

Then in order to do the final adjustments and controls a committee has been composed among the academics at Uludag University. The committee was consisted of 4 academics from different departments such as: English Language 
Department, Turkish Language Department, Work Psychology Department and Business Administration Department. Then the original authors checked the latest version of the translations. To take the feedbacks from the participants survey has been conducted among 30 academics first. The preliminary analysis and the feedbacks were also considered by the committee and after very minor changes the survey was ready to go.

\subsection{Participants}

The Survey has been distributed in Bursa-Turkey. Data have been collected from 288 employees (48\% response rate after the removal of the cases with missing data) with different occupational backgrounds. The sample consisted of 150 men (52.1\%) and 126 women (43.8\%) (Missing data: 12 ). Their mean age was 34.25 years (SD = 8.96), ranging from 16 to 65 years old. Average work experience was 12.17 years $(S D=9.31)$. 163 of the participants were married $(56.6 \%)$. Average weekly working hours were found $51.55(S D=10.46)$.

\subsection{Measures}

The Work Related Quality of Life (WRQoL) scale has six dimensions within 23 items and all of the items were measured on a five-point ( 1 = Strongly Agree through to Strongly Disagree $=5$ ) Likert scale (Van Laar et al., 2007). Three reversed items were recoded while computing the overall WRQoL. The scale is partly based on the study of Sirgy and friends (2001). To evaluate the internal and external factors the Van Laar and friends (2007) made use of Loscocco and Roschelle's (1991) work. WRQoL is based on the idea that the many facets of work experience can't be effectively explained separately, and need to be considered together (Edwards et al., 2009).

- $\quad$ General Well-Being (GWB) -six items-: Items are related to happiness and life satisfaction: e.g. "Generally things work out well for me".

- Home-Work Interface (HWI) -three items-: Items are related to issues of accommodating family and work commitments, e.g. "My current working hours/patterns suit my personal circumstances"

- Job and Career Satisfaction (JCS) -six items- e.g. "I am satisfied with the career opportunities available to me at the organization"

- $\quad$ Control at Work (CAW) (three items): Items are related to being able to have control over decisions, e.g. "I am involved in decisions that affect me in my own area of work"

- Working Conditions (WCS) -three items-: Items are related to the physical working environment: e.g. "The working conditions are satisfactory".

- $\quad$ Stress at Work (SAW) -two items-: Items are related to demands. e.g. "I often feel under pressure at work"

The Job Related Affective Well-Being Scale has four dimensions (Enthusiasm, Anxiety, Depression, Relaxation) within 12 items and all of the items were measured on a 6-point scale $(1=$ Never, $2=$ Occasionally, 3 = Some of The Time, 4 $=$ Much of The Time, 5 = Most of The Time, 6 = All of The Time). Sevastos (1996) converted the two bipolar scale of Warr (1990) into four monopolar scale in his doctoral dissertation. The scale is concerned with how their job has been making the participants feel over the past few weeks (Sevastos, 1996). 12 items are Gloomy, Calm, Anxious, Enthusiastic, Motivated, Worried, Restful, Tense, Depressed, Optimistic, Relaxed and Miserable respectively. Six negative items were recoded while computing overall job related affective well-being.

\section{Results}

The scores of all items were recorded and the distributions checked. Skewness and kurtosis for almost all of the WRQL and Job Related Affective Well-Being Scale items fell between -1.00 and +1.00 with few minor exceptions. KMO value was 0.94, which is greater than expected 0.90, and a significant Barlett's test $(p<0.05)$ demonstrated that the data set was appropriate for factor analysis.

Because we were testing existing measures with solid conceptual models we ran both first order and second order Confirmatory Factor Analyses (CFA) by using Lisrel software versions 8.51 and 8.80 . Fit indices were evaluated according to following criterion. $0 \leq \chi 2 \leq 2 \mathrm{df}$ good fit, $0 \leq \chi 2 \leq 3 \mathrm{df}$ acceptable fit, $0.90 \leq \mathrm{CFI} \leq 0.95$ acceptable fit, 0.95 $\leq \mathrm{CFI} \leq 1.00$ good fit , $0.05 \leq$ SRMR $\leq 0.10$ acceptable fit, $0 \leq \mathrm{SRMR} \leq 0.05$ good fit, $0.05 \leq \mathrm{RMSEA} \leq 0.08$ acceptable fit, $0 \leq$ RMSEA $\leq 0.05$ good fit , $0.90 \leq \mathrm{GFI} \leq 0.95$ acceptable fit, $0.95 \leq \mathrm{GFI} \leq 1.00$ good fit , $0.85 \leq \mathrm{AGFI} \leq$ 0.90 acceptable fit, $0.90 \leq$ AGFI $\leq 1.00$ good fit (Bayram, 2010; Hu \& Bentler, 1999; Jöreskog \& Sörbom, 1993; Bentler, 1990; Dunn et al., 1993).

The original structure of the WRQoL scale consisted of 6 factors and it was tested several times by Van Laar and friends and statistics showed a good fit model in each study (Van Laar et al., 2007; Edwards et al., 2009). Due to this fact 
CFA (Confirmatory Factor Analysis) first carried out and original factor structure was imposed to the Turkish participants' responses. The factor structure was shown in Figure 1. Fit indices did not indicate an acceptable model $(X 2(194)=$ $600.51, \mathrm{RMSEA}=.085, \mathrm{CFI}=.82, \mathrm{SRMR}=.076, \mathrm{GFI}=.83, \mathrm{AGFI}=.78)$. When we further investigated the standardized factor loadings we have found that 3 items had low standardized factor loadings and they appeared to be disrupting the model structure. The translations of those items were checked again and we have concluded that the translations carried the intended meanings of the original items. After discussions with the original authors it has been decided to remove items 2, 10 and 14 and continue the analysis with the new structure embodying 20 items.

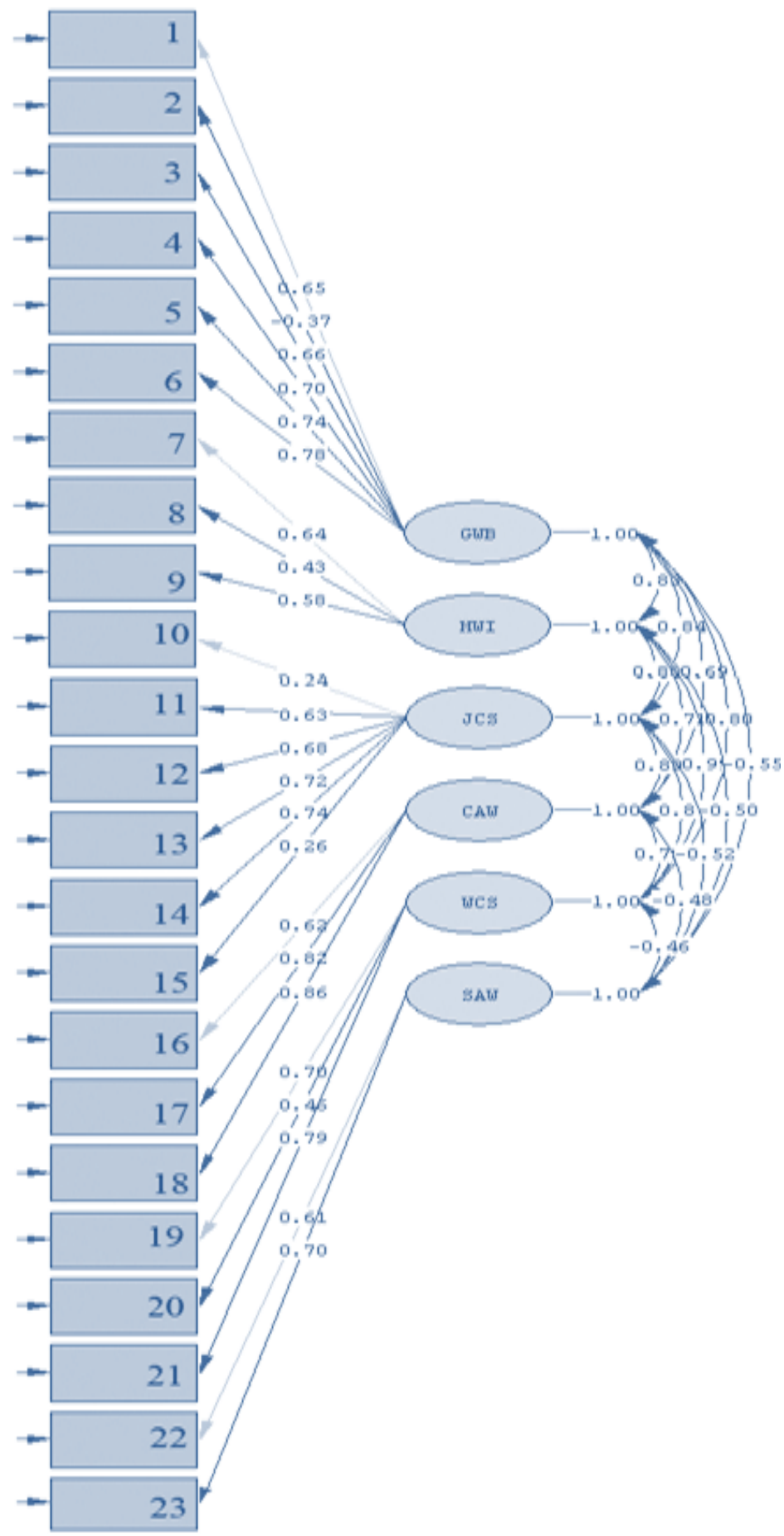

Figure 1. First Order CFA with Original Factor Structure of WRQoL (23 items)

The new factor structure was shown in Figure 2. Fit indices for the first order factor analysis, (allowing 6 factors to correlate) of the 20-item model indicate an acceptable model fit. $(X 2(155)=394.362, \mathrm{RMSEA}=.073, \mathrm{CFI}=.92, \mathrm{SRMR}=$ $.059, \mathrm{GFI}=.93, \mathrm{AGFI}=.88)$. The standardized factor loadings of the individual items are also satisfactory. 


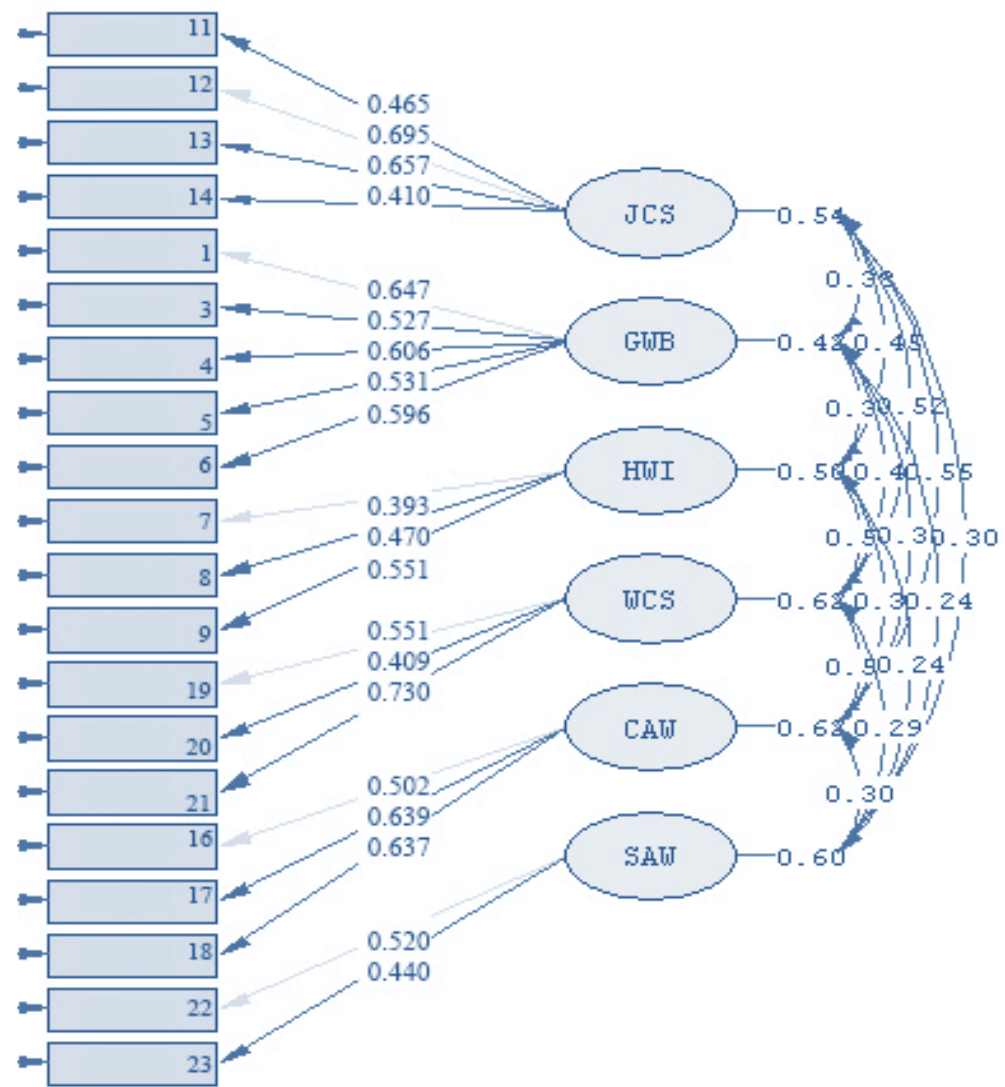

Figure 2. First Order CFA of WRQLL with 20 items and 6 Factors

The second order CFA of the new factor structure and the standardized factor loadings of WRQoL dimensions were shown in Figure 3. Fit indices for the second order factor analysis model indicate acceptable to good model fit. (X2(129) = 278.213, RMSEA $=.063, \mathrm{CFI}=.93, \mathrm{SRMR}=.058, \mathrm{GFI}=.92, \mathrm{AGFI}=.87$ ).

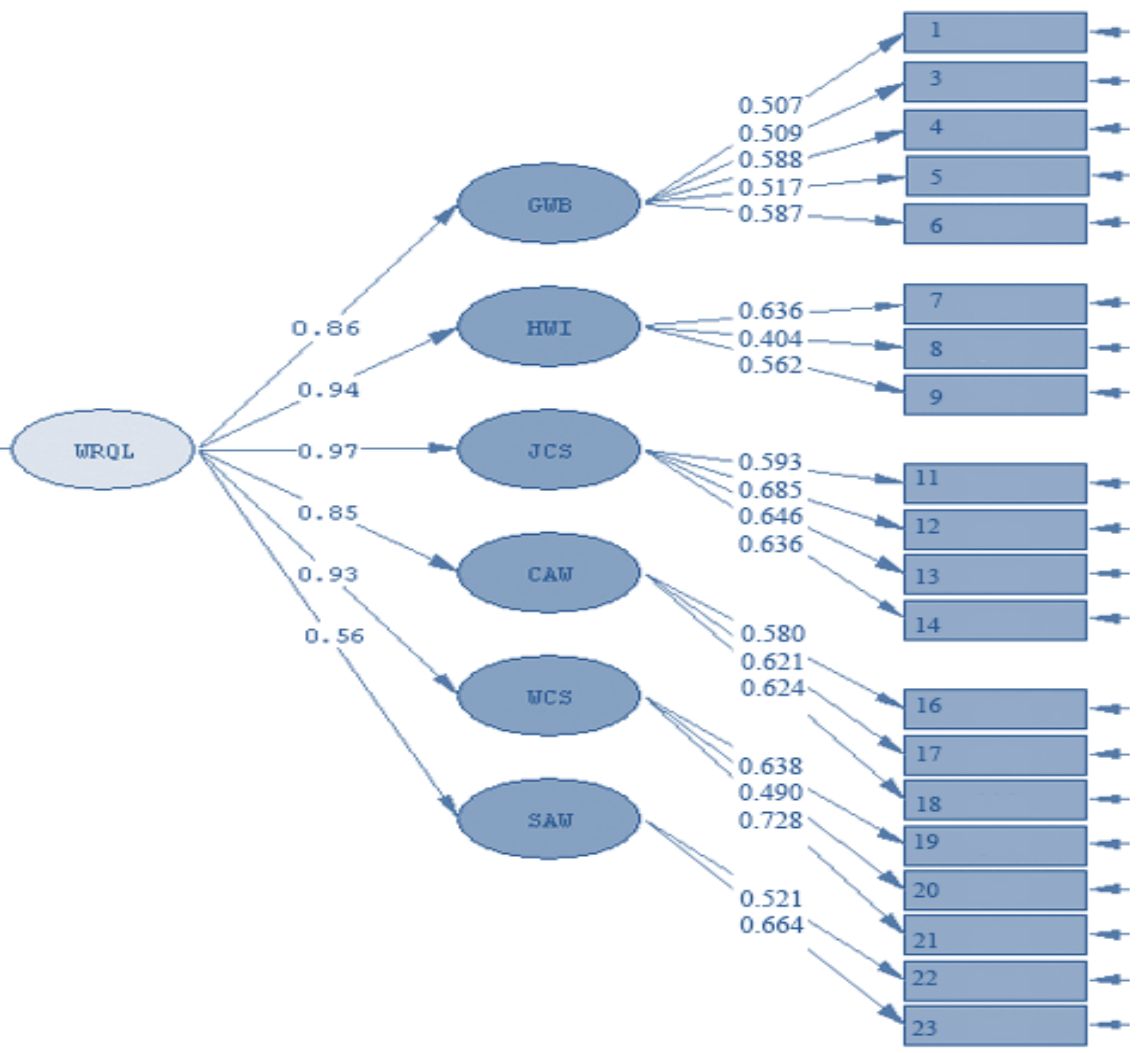

Figure 3. Second Order CFA of WRQoL with 20 items and 6 Factors 


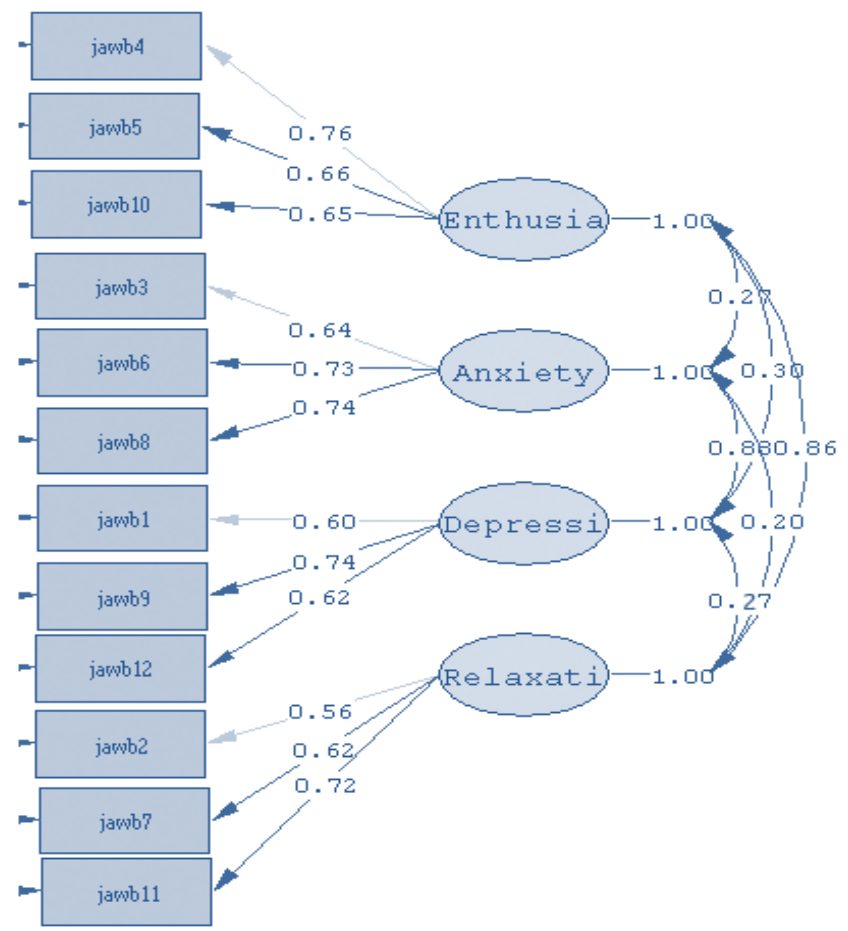

Figure 4. First Order CFA of Job Related Affective Well-Being Scale

The CFA of the original factor structure of the Job Related Affective Well-Being scale imposed to participants' responses was shown in Figure 4. Fit indices for the first order factor analysis, (allowing 4 factors to correlate) of the original model indicate a good model fit. $(X 2(48)=102.218, \mathrm{RMSEA}=.063, \mathrm{CFI}=.95, \mathrm{SRMR}=.049, \mathrm{GFI}=.94, \mathrm{AGFI}=.91)$. The standardized factor loadings of the individual items are also satisfactory.

The second order CFA and the standardized factor loadings of job related affective well-being scale was shown in Figure 5. Fit indices for the second order factor analysis model also indicate a good model fit. $(X 2(36)=81.457$, RMSEA $=.074, \mathrm{CFI}=.95, \mathrm{SRMR}=.043, \mathrm{GFI}=.96, \mathrm{AGFI}=.89)$. The regression weights of the enthusiasm, anxiety, depression and relaxation sub-scales were $.99, .42, .44$ and .84 respectively.

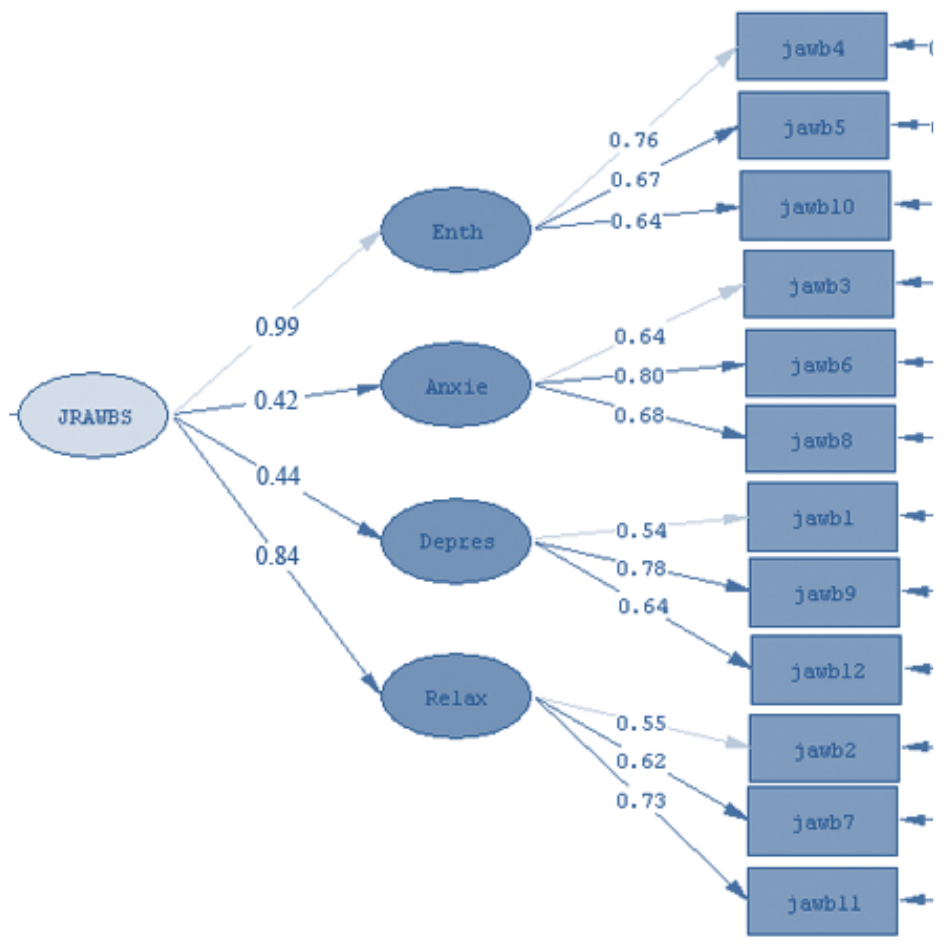

Figure 5. Second Order CFA of Job Related Affective Well-Being Scale 
Table 2. Cronbach's Alpha Values of WRQOL

\begin{tabular}{|l|l|}
\hline Factor & Cronbach's Alpha \\
\hline WRQoL -20 items & .89 \\
\hline GWB -5 items & .74 \\
\hline JCS -4 items & .76 \\
\hline HWI -3 items & .67 \\
\hline WCS -3 items & .70 \\
\hline CAW -3 items & .73 \\
\hline SAW -2 items & .69 \\
\hline
\end{tabular}

Results of the reliability analysis are shown in Table 2 and Table 3. Cronbach's alpha levels of the factors indicate both instruments are reliable. Only two factors are under desired .70 level. However considering they are consisted of 2 and 3 items might reveal the cause of the decrease in Cronbach's alpha levels (Streiner, 2003; Nunnaly, 1978).

Table 3. Cronbach's Alpha Values of JRAWBS

\begin{tabular}{|l|l|}
\hline Factor & Cronbach's Alpha \\
\hline JRAWBS - 12 items & .89 \\
\hline Enthusiasm -3 items & .74 \\
\hline Anxiety -3 items & .76 \\
\hline Depression -3 items & .67 \\
\hline Relaxation -3 items & .70 \\
\hline
\end{tabular}

We have conducted correlational analysis in order to assess the relationships between Work Related Quality of Life and Job Related Affective Well-Being in all dimensions. Significant negative and positive correlations have been detected at desired 0.01 and 0.05 levels. Pearson correlation coefficients are shown in Table 4.

Table 4. Correlational Analysis of WRQOL and JRAW scales

\begin{tabular}{|l|l|l|l|l|l|l|l|l|l|l|l|l|}
\hline & GWB & HWI & JCS & CAW & WCS & WRQL & SAW & ENT & ANX & DEP & REL & JWB \\
\hline GWB & 1 & & & & & & & & & & & \\
\hline HWI &, $601^{* *}$ & 1 & & & & & & & & & & \\
\hline JCS &, $646^{* *}$ &, $558^{* *}$ & 1 & & & & & & & & & \\
\hline CAW &, $497^{* *}$ &, $435^{* *}$ &, $697^{* *}$ & 1 & & & & & & & & \\
\hline WCS &, $583^{* *}$ &, $642^{* *}$ &, $627^{* *}$ &, $546^{* *}$ & 1 & & & & & & & \\
\hline WRQL &, $830^{* *}$ &, $767^{* *}$ &, $852^{* *}$ &, $764^{* *}$ &, $802^{* *}$ & 1 & & & & & & \\
\hline SAW &,$- 187^{* *}$ &,$- 207^{* *}$ &,$-173^{* *}$ &,$- 167^{* *}$ &,$- 164^{* *}$ &,$- 351^{* *}$ & 1 & & & & & \\
\hline ENTH &, $477^{* *}$ &, $432^{* *}$ &, $492^{* *}$ &, $326^{* *}$ &, $420^{* *}$ &, $547^{* *}$ &,$- 237^{* *}$ & 1 & & & & \\
\hline ANX &,$- 334^{* *}$ &,$- 265^{* *}$ &,$- 313^{* *}$ &,$- 345^{* *}$ &,$- 304^{* *}$ &,$- 421^{* *}$ &, $293^{* *}$ &,$- 210^{* *}$ & 1 & & & \\
\hline DEPP &,$- 303^{* *}$ &,$- 277^{* *}$ &,$- 285^{* *}$ &,$- 254^{* *}$ &,$- 304^{* *}$ &,$- 412^{* *}$ &, $383^{* *}$ &,$- 235^{* *}$ &, $637^{* *}$ & 1 & & \\
\hline RELAX &, $403^{* *}$ &, $309^{* *}$ &, $337^{* *}$ &, $262^{* *}$ &, $339^{* *}$ &, $410^{* *}$ &,$- 198^{* *}$ &, $619^{* *}$ &,$- 173^{*}$ &,$- 193^{*}$ & 1 & \\
\hline JWB &, $538^{* *}$ &, $459^{* *}$ &, $513^{* *}$ &, $424^{* *}$ &, $490^{* *}$ &, $637^{* *}$ &,$- 394^{* *}$ &, $733^{* *}$ &,$- 720^{* *}$ &,$- 706^{* *}$ &, $647^{* *}$ & 1 \\
\hline
\end{tabular}

**. Correlation is significant at the 0.01 level (2-tailed).

*. Correlation is significant at the 0.05 level (2-tailed).

We also have investigated the means of the scales with all sub-scales in terms of age, gender, age, working hours and experience by using independent samples t-test and one way ANOVA. Only the means of the stress at work (SAW) levels showed a significant difference $(p<0.05)$ according to the weekly working hours of the participants. The less the 
employees work the lower their stress levels (less than $36 \mathrm{~h} /$ week $=5.7 \mathrm{SAW}, 36-45 \mathrm{~h} /$ week $=6.2 \mathrm{SAW}$, more than 45 $\mathrm{h} /$ week $=7.8 \mathrm{SAW}$ ). No significant differences were found in any other analysis.

\section{Discussion}

The original factor structure of the WRQoL did not give rise to good fit indices in this study. According to the standardized factor loadings, one item from Generel Well-Being sub-scale and two items from Job and Career Satisfaction sub-scale with low levels have been removed from the survey. After removing the three items the CFA results and standardized factor loadings became satisfactory for both first order and second order CFA.

The relationship between the Stress at Work (SAW) subscale and other WRQLL factors produced the weakest correlations for the present study and both that of Van Laar and friends (2007) and Edwards and friends (2009). Stress at Work (SAW) also had the weakest regression weight (0.56) of the all WRQL factors in the second order CFA like the studies of Van Laar and friends (2007) and Edwards and friends (2009). These results might be an indication for a further development necessity of SAW factor. Also Home Work Interface subscale showed a lower but close level of Cronbach's alpha (.67) considering the desired level is .70 (Nunnaly, 1978). After our discussions with the original authors and bearing the CFA results in mind we have decided to keep these items in the scale. All in all, we might suggest that the Turkish version of the WRQoL scale is still valid and reliable with 20 items and 6 sub dimensions.

The Turkish version of the job related affective well being scale showed consistent results with the original study of Sevastos (1996). All factors and items remained with good fit indices obtained from first order and second order CFA. The Cronbach's alpha scores confirmed the reliability of the instrument. 12-item Four Factor Congeneric Model of Jobrelated Affective Well-being Scale (Sevastos, 1996) might be used in the further studies in Turkish context with the same structure of the original study.

Depression and Anxiety had negative correlations with GWB, HWI, WCS, CAW, JCS, Enthusiasm, Relaxation, overall WRQoL and Job Related Affective Well-Being, positive correlations with SAW in the present study. SAW also had negative correlations with GWB, HWI, WCS, CAW, JCS, Enthusiasm, Relaxation, overall WRQoL and Job Related Affective Well-Being. All the other sub-scales and overall scales showed a significant positive correlation with other sub scales and overall scales.

No significant differences in the means of the factors were found according to age, gender, age, working hours and experience variables except the relationship between SAW and weekly working hours. The SAW scores showed a significant decrease while participants were working for fewer hours.

Both of the scales need further research in a Turkish context with datasets from different occupational groups. Longitudinal studies might also enhance the usefulness of the measures. Authors of the current study are planning to test the relationships of QWL and employee well-being with other organizational aspects notably leadership using WRQoL and JRAWB scales. We are hoping to contribute to the literature by increasing the quantity and quality of the research on QWL and employee well-being in Turkey with the use of these instruments. Measuring QWL and employee well-being might also actualize the practical implications like redesigning of jobs, improvements in the workplace, working hours/patterns and environmental conditions.

\section{References}

Aytaç, S. (2006) Çalışanların Işlerine Illişkin Duygularının Stres Üzerindeki Etkisi, İstanbul Üniversitesi Iktisat Fakültesi Mecmuası, Prof. Dr. Toker Dereli'ye Armağan, 55(1)

Bayır Toplu, D. (1999). Çalışma Yaşamının Kalitesinin Geliştirilmesi: Türkiye'deki Kamu Kurum Arşivleri Örneği. Türk Kütüphaneciliği 13(3) pp. 223-251

Bayram, N. (2010). Yapısal Eşitlik Modellemesine Giriş: Amos Uygulamaları. Bursa: Ezgi.

Bayram N., Kuşdil, M. E., Aytaç, S., Bilgel, N. (2004) Işe Illişkin Duyuşsal lyilik Algısı Ölçeğinin (Job-Related Affective Well Being-JAWS) Türkçe Versiyonunun Güvenilirlik Çalışması, Marmara Üniversitesi Sosyal Bilimler Enstitüsü Dergisi: Öneri, 6(22) pp. 1-7

Beach, D. S. (1980). Personnel: The Management of People at Work (4 th Ed.). New York: Mcmillan Publishing

Bentler, P.M. (1990), Comparative Fit Indexes in Structural Models, Psychological Bulletin, 107 (2), pp. 238-46.

Bowditch, J. L., Buono, A. F. (1997). A Primer On Organizational Behavior. USA: Wiley.

Briner, R.B. (1997) Beyond stress and satisfaction: Understanding and managing emotions at work. Paper presented at the Occupational Psychology Conference, Blackpool

Can, A. (1991) Çalışma Hayatının Kalitesinin Geliştirilmesi, Ankara, I. Verimlilik Kongresi MPM Yayınları: 454: 89-101.

Carayon, P., Honaker, P., Marchand, S. and Schwarz, J., (2003) Job Characteristics and Quality of Working Life in the IT Workforce, Proceedings of Research Seminar, Department of Industrial Engineering. University of Wisconsin.

Cummings, T.G and Vorley, C.G. (2009). Organizational Development \&Change, 9th Edition, South Western Cengage Learning, USA. 
Daniels, K. (2000) Measures of five aspects of affective well-being at workMeasures of five aspects of affective well-being at work, Human Relations 53(2): 275-294

Davoine L., Erhel, C., Guergoat-Lariviere, M. (2008), A Taxonomy of European Labour Markets Using Quality Indicators, Centre D'etudes De L'emploi, Mai 2008, No.45.

Davis, L. E., Trist, E. L. (1974). Improving The Quality Of Working Life: Sociotechnical Case Studies. in James O'toole (Edt.) Work And The Quality Of Life Resource Papers For Work In America (p.246- 279). MIT Pres.

Diener, E. \& Larsen, R.J. (1993) The experience of emotional well-being. In M.Lewis and J.M. Havilland (Eds), Handbook of emotions. New York: Guildford Press

Diener, E.; Lucas, R.E.; Smith, H.L.; Suh, E.M. (1999) Subjective Well-Being: Three Decades of Progress. Psychological Bulletin 175(2) pp. 276-302

Dikmetaş, E. (2006). Hastane Personelinin Çalışma / Iş Yaşam Kalitesine Yönelik Bir Araştırma. Ç.Ü. Sosyal Bilimler Enstitüsü Dergisi, 15(2) pp.169-182

Dunn, G., Everitt, B. \& Pickles, A.(1993) Modelling covariances and latent variables using EQS. London: Chapman \& Hall,.

Eaton, A. E. (1990). The Extent and Determinants of Local Union Control of Participative Programs. Industrial and Labor Relations Review, 43(5), pp. 604-620.

Edwards, J.A.,Van Laar, D. ve Easton, S. (2009). "The Work-Related Quality of Life (WRQoL) scale for higher education employees". Quality in Higher Education, 15(3), pp. 207-219

Erdem, M. (2010). Öğretmen Algılarına Göre Liselerde Iş Yaşamı Kalitesi ve Örgütsel Bağılııla Illişkisi. Educational Administration: Theory and Practice, 16(4) pp. 511-536

European Foundation for the Improvement of Living and Working Conditions (2002) [Online] Available: http://www.eurofound.europa.eu/pubdocs/2002/12/en/1/ef0212en.pdf (July, 15 2012)

Fernandes, E. C. (1996). Qualidade de vida no trabalho: como medir para melhorar. Salvador, BA : Casa da Qualidade.

Gundogan, N. (2010). "Istihdam Politikalarının Bir Hedefi Olarak Iş Kalitesi ve Uluslararası Kuruluşların Bu Konudaki Yaklaşımları", Çimento-Işveren Dergisi, Ocak 2010.

Hackman, J.R., ve Oldham, G.R.. (1980). Work redesign. Reading. M.A: Addison-Wesley.

Hu, L.T. ; Bentler, P.M. (1999), Cutoff Criteria for Fit Indexes in Covariance Structure Analysis: Conventional Criteria Versus New Alternatives, Structural Equation Modeling, 6 (1), 1-55.

Huzzard, T. (2003). The Convergence of the Quality of Working Life and Competitiveness, Arbetsliv -Omvandling. National Institute for Working Life. Sweden.

Ivancevich, J. M., \& Matteson, M. T. (1996). Organizational Behaviour and Management (4th ed.). Chicago, IL: Irwin

Jöreskog, K. and Sörbom, D. (1993), LISREL 8: Structural Equation Modeling with the SIMPLIS Command Language. Chicago, IL: Scientific Software International Inc

Van Katwyk, P. T., Fox, S., Spector, P. E., \& Kelloway, E. K. (2000). Using the Jobrelated Affective Well-being Scale (JAWS) to investigate affective responses to work stressors. Journal of Occupational Health Psychology, 5, 219-230

Kaymaz, K. (2003). Çalışma Yaşamında Kalite. İş, Güç Endüstri Illişkileri ve Insan Kaynakları Dergisi. 5(1)

Limongi-França, A. C. (2004). Qualidade De Vida No Trabalho: Conceitos E Práticas Na Sociedade Pósindustrial. Atlas. São Paulo.

Newstrom, J. W. \& Davis, K. (1997). Organizational Behavior Human Behavior at Work (10th Ed.). Mcgraw-Hill.

Nunnaly, J. (1978). Psychometric theory. New York: McGraw-Hill

Reena, G., Jayan, C. (2012). Role Of Quality of Work Life on The Job Attitude and Personal Effectiveness of Engineering College Teachers, South Asian Academic Research Journals, Academicia 2(6)

Rethinam, G.N \& Ismail, M. (2008). Constructs of Quality of Work Life: A Perspective of Information and Technology Professionals, European Journal of Social Sciences, 7(1)

Runcie, J. F. (1980). Dynamic Systems and the Quality of Work Life. Personnel. 57(6) pp. 13-24.

Robbins, S. P. (1989). Organizational Behavior: Concepts, Controversies, and Applications. NJ: Prentice Hall.

Robertson, I. \& Cooper, C. (2011) Well-being: Productivity and Happiness at Work, Eastbourne, Palgrave Macmillan

Russell, J.A. (1980) Affective space is bipolar. Journal of Personality and Social Psychology, 39, 1152-68.

Schulze, N. (1998). Yaşam Kalitesini Yükselten Temel Unsur Olarak İşin Insancıllaştırılması, 6. Ergonomi Kongresi, M.P.M. Yayınları No:622, Ankara, 1998.

Sevastos, P., Smith, L. \& Cordery, J.L. (1992) Evidence on the reliability and construct validity of Warr's (1990) measures of well-being and mental health measures. Journal of Occupational Psychology, 65, pp. 33-50.

Sevastos, P.P. (1996). Job-Related Affective Well-Being and Its Relation to Intrinsic Job Satisfaction. Unpublished PhD Thesis, Curtin University, Perth, Australia

Serey, T.T. (2006). Choosing a Robust Quality of Work Life, Business Forum, 27(2), pp. 7-10.

Sirgy, M.J., Efraty, D., Siegel, P., \& Lee, D.J. (2001). A New Measure Of Quality Of Work Life (QWL) Based On Need Satisfaction and Spillover Theory. Social Indicators Research, 55 (3), pp. 241-302.

Solmuş, T. (2000). Iş Yaşamında Kalite ve Kaliteyi Arttırmaya Yönelik Program. Türk Psikoloji Bülteni, 18

Streıner D. (2003) Starting at the beginning: an introduction to coefficient alpha and internal consistency. Journal of personality assessment. 80 pp. 99-103.

Timossi,L., Pedroso, B., Francisco, A., Pilatti, L. (2008). Evaluation of QWL: An Adaptation from the Walton's QWL Model. XIV International Conference On Industrial Engineering and Operations Management. Rio de Janeiro. Brazil

Ustundag; N. (1999) Akıllı binaların tesis yönetimi ve iş yaşamı kalitesi üzerindeki etkileri. Unpublished PhD Thesis, Istanbul Üniversitesi, Sosyal Bilimler Enstitüsü, İstanbul. 
Van Laar, D. L., Edwards, J. A. \& Easton, S. (2007). The Work-Related Quality of Life (QoWL) scale for Healthcare Workers. Journal of Advanced Nursing. 60(3), 325-333.

Walton, R. E. (1972). How to Counter Alienation in the Plant. Harvard Business Review, 50(6), pp. 70-81.

Walton, R. E. (1973). Quality of working life: what is it?. Sloan Management Review. 15(1) pp. 11-21.

Warr, P. (1990a) The measurement of well-being and other aspects of mental health. Journal of Occupational Psychology, 63, pp.193210.

Warr, P. (1990b) Decision latitude, job demands, and employee well-being. Work \& Stress, 4, pp.285-294.

Warr, P. (1992) Age and occupational well-being. Psychology and Aging, 7, pp. 37-45.

Warr, P. (1994) A conceptual study for the work and mental health. Work \& Stress, 8, pp. 84-97.

Wyatt, T. A. \& Wah, C. Y. (2001). Perceptions of QWL: A study of Singaporean employees development. Research and Practice in Human Resource Management, 9(2), pp. 59-76. 